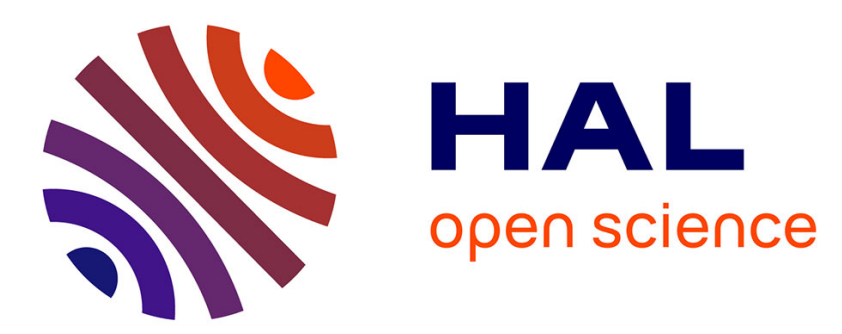

\title{
Indirect electroreduction as pretreatment to enhance biodegradability of metronidazole.
}

I. Saidi, Isabelle Soutrel, Didier Floner, Florence Fourcade, N. Bellakhal, Abdeltif Amrane, Florence Geneste

\section{- To cite this version:}

I. Saidi, Isabelle Soutrel, Didier Floner, Florence Fourcade, N. Bellakhal, et al.. Indirect electroreduction as pretreatment to enhance biodegradability of metronidazole.. Journal of Hazardous Materials, 2014, 278C, pp.172-179. 10.1016/j.jhazmat.2014.06.003 . hal-01017026

\section{HAL Id: hal-01017026 \\ https://hal.science/hal-01017026}

Submitted on 8 Oct 2014

HAL is a multi-disciplinary open access archive for the deposit and dissemination of scientific research documents, whether they are published or not. The documents may come from teaching and research institutions in France or abroad, or from public or private research centers.
L'archive ouverte pluridisciplinaire HAL, est destinée au dépôt et à la diffusion de documents scientifiques de niveau recherche, publiés ou non, émanant des établissements d'enseignement et de recherche français ou étrangers, des laboratoires publics ou privés. 


\section{Indirect electroreduction as pretreatment to enhance biodegradability of} metronidazole

I. Saidi ${ }^{1,3,4}$, I. Soutrel ${ }^{1,2,4}$ D. Floner ${ }^{1,4}$, F. Fourcade ${ }^{1,2,4}$, N. Bellakhal ${ }^{3}$, A. Amrane ${ }^{* 1,2,4}$, F. Geneste $^{* 1,4}$

1) Institut des Sciences Chimiques de Rennes, Université de Rennes 1, UMR-CNRS 6226, Campus de Beaulieu, 35042 Rennes Cedex, France.

2) Institut des Sciences Chimiques de Rennes, Ecole Nationale Supérieure de Chimie de Rennes, UMR-CNRS 6226, Avenue du Général Leclerc, CS 50837, 35042 Renne Cedex 7, France.

3) Laboratoire de recherche de Catalyse d'Electrochimie de Nanomatériaux et leurs applications et de didactique CENAD, Institut National des Sciences Appliquées et de Technologie (INSAT), B.P.Nº76, 1080 Tunis Cedex, Tunisie.

4) Université Européenne de Bretagne, 35000, France

\section{Abstract}

The removal of metronidazole, a biorecalcitrant antibiotic, by coupling an electrochemical reduction with a biological treatment was examined. Electroreduction was performed in a home-made flow cell at $-1.2 \mathrm{~V} / \mathrm{SCE}$ on graphite felt. After only one pass through the cell, analysis of the electrolyzed solution showed a total degradation of metronidazole. The biodegradability estimated from the $\mathrm{BOD}_{5} / \mathrm{COD}$ ratio increased from 0.07 to 0.2 , namely below the value usually considered as the limit of biodegradability (0.4). In order to improve these results, indirect electrolysis of metronidazole was performed with a titanium complex known to reduce selectively nitro compounds into amine. The catalytic activity of the titanium complex towards electroreduction of metronidazole was shown by cyclic voltammetry analyses. Indirect electrolysis led to an improvement of the biodegradability from 0.07 to 0.42. To confirm the interest of indirect electroreduction to improve the electrochemical pretreatment, biological treatment was then carried out on activated sludge after direct and indirect electrolyses; different parameters were followed during the culture such as $\mathrm{pH}$, TOC

\footnotetext{
* Corresponding authors. Tel. +33 223235965; Fax. +33 223236939. E-mail address: Florence.Geneste@univrennes1.fr (F. Geneste), Abdeltif.Amrane@univ-rennes1.fr (A. Amrane)
} 
and metronidazole concentration. Both electrochemical processes led to a more efficient biodegradation of metronidazole compared with the single biological treatment, leading to an overall mineralization yield for the coupling process of $85 \%$.

Keywords: Metronidazole, Indirect electroreduction, Titanium complex, combined process, Biological treatment

\section{Introduction}

Metronidazole (MNZ) 1 (Table 1) is an antibiotic extensively used for treating infection caused by anaerobic bacteria, protozoa and bacteroide such as trichromoniasis, vaginosis, amoebiasis and gingivitis [1]; it has also been used as an additive in poultry and fish feed to eliminate parasites [2]. Nowadays, it is one of the most used drugs worldwide and it appears in the essential drug list of the world health organization [3]. Table 1 recapitulates the physico-chemical characteristics of metronidazole.

Residual concentrations (from 1 to $10 \mathrm{ng} \mathrm{L}^{-1}$ ) have been found in surface waters and wastewater $[4,5]$. Because of the non-degradability, toxicity, potential mutagenicity and carcinogenity of metronidazole wasterwaters originating from the production of metronidazole and from industrial activities cause adverse effects to humans and the ecological environment $[3,6]$. Therefore, the elimination of metronidazole from wastewater is of significant environmental, technical, and commercial significance. 
Table 1: Physico-chemical properties of metronidazole

\begin{tabular}{cc}
\hline Structure & 171.161 \\
\hline Molecular formula & $\mathrm{C}_{6} \mathrm{H}_{9} \mathrm{~N}_{3} \mathrm{O}_{3}$ \\
$\mathbf{M W}\left(\mathbf{g ~ m o l}^{-1}\right)$ & $159-163$ \\
$\mathbf{M p}\left({ }^{\circ} \mathbf{C}\right)$ & 9.5 \\
$\mathbf{S}_{\mathbf{W}}(\mathbf{g} / \mathbf{L})$ & $2.55,14.44$ \\
\hline $\mathbf{p K}$ & \\
\hline
\end{tabular}

Being non-biodegradable [7] and highly soluble in water, metronidazole is difficult to be removed and hence can accumulate in the aquatic environment [8]. Many technologies concerning metronidazole removal have been reported, such as adsorption $[9,10]$, reduction of nanoscale zero-valent iron particles [2], biological methods [11,12], ozonation technology [13], photolysis [4,14], Fenton and photo-Fenton processes [15], heterogeneous photocatalysis [16], and Electro-Fenton process with a $\mathrm{Ce} / \mathrm{SnO}_{2}-\mathrm{Sb}$ coated titanium anode [17].

Adsorption of metronidazole consists only in a physical transfer from water to a solid phase without any degradation $[9,10]$. The removal of metronidazole by biological method involved long periods of treatment, while the obtained efficiency was usually very low [11, 12]. Oxidations processes are efficient but can result in the formation of intermediates with higher toxicity than the parent compound, metronidazole; their removal from the water is thus also needed [5, 13-17]. Complete mineralization of metronidazole present in wastewater appears therefore to be the most relevant option [17]; for this purpose and even if advanced oxidation processes (AOP) lead to a complete mineralization, their main drawbacks are their cost and their lack of selectivity. 
In recent years, coupled processes, such as electrochemical (oxidation/reduction) and biological treatment, have received growing attention for their efficiency in complete mineralization of biorecalcitrant compounds with the objective to reduce operating costs [1828]. The pretreatment is carried out to increase the biodegradability of the effluent and to reduce its toxicity. This technology has been applied for the removal of several recalcitrant molecules such as phosmet an organophosphorous insecticide [23, 24], a chlorinated phenoxy herbicide 2,4-Dichlorophenoxyacetic $[25,26]$ and tetracycline an extensively used antibiotic [27]. More recently [28], we reported the efficiency of the electrochemical process (direct oxidation) as a pretreatment method for enhancing the biodegradability of sulfamethazine, a biorecalcitrant antibiotic. The optimization of the operating conditions (flow rate and applied potential) allowed to improve its biodegradability, since the $\mathrm{BOD}_{5}$ on $\mathrm{COD}$ ratio increased from 0.06 to 0.58 . These results emphasized the interest of selective oxidation/reduction processes as pretreatment before a biological treatment to remove compounds.

To confirm the relevance of such a coupling process, namely the coupling of an electroreduction process (direct / indirect) with a biological treatment, its extension to another family of pollutants, nitrocompounds, was therefore investigated; and for this purpose metronidazole has been considered as a model compound. Indeed, it contains a nitro group that is known to reduce the biodegradability of molecule $[29,30]$. The reduction of this nitro group into amino compounds should increase the biodegradability of the compound allowing a rapid and efficient subsequent biological treatment. Two electrochemical methods were tested to reduce the nitro group: a direct cathodic reduction in acidic medium and indirect cathodic reduction using a catalyst. Indirect electrolysis [31,32] has attracted a lot of attention because it decreases the energy consumption and can offer higher selectivity than direct electrolysis. The catalyst reacts with the substrate and is subsequently regenerated in its active form at the electrode as illustrated in Fig.1 with the example of an indirect electroreduction. 


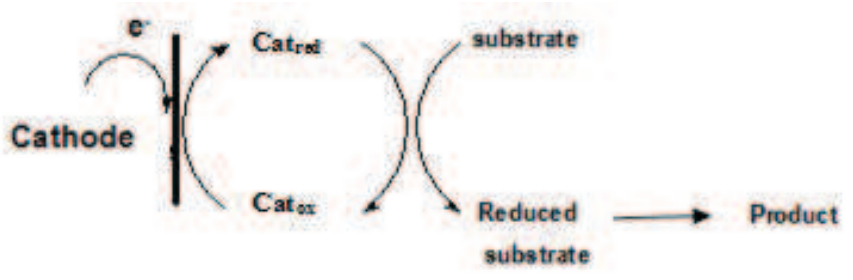

Fig. 1. Principle of indirect electrolysis exemplified by a reduction

For indirect electrolysis, a titanium complex $\left(\left(\mathrm{C}_{5} \mathrm{H}_{5}\right)_{2} \mathrm{Ti}^{+}\right)$was used as catalyst, since its ability to selectively reduce in acidic medium nitrobenzene derivatives into amino compounds has been previously demonstrated $[33,34]$. The pretreatment was achieved in an electrochemical flow cell using a graphite felt electrode of high specific area, allowing a rapid and quantitative transformation of polluted solutions. The direct and indirect electrochemical reductions of metronidazole are reported here. The biodegradability of the resulting products was first estimated using classical parameters and then validated through a biological treatment.

\section{Materials and Methods}

\subsection{Chemicals and materials}

Metronidazole (MNZ) with $99 \%$ of purity and titanocene dichloride $\left(\mathrm{C}_{5} \mathrm{H}_{5}\right)_{2} \mathrm{TiCl}_{2}$ were obtained from TCI (Tokyo Chemical Industry). $\mathrm{H}_{2} \mathrm{SO}_{4}$ (purity $99 \%$ ) was purchased from VWR (Van Waters \& Rogers). Acetonitrile (purity 99.9\%) was HPLC grade obtained from Sigma-Aldrich. Graphite felt (Recycled Vein Graphite RVG 4000) was supplied by Mersen (France). Its specific area measured by the BET (Brunauer, Emett and Teller) method, its volume density and its carbon content were $0.7 \mathrm{~m}^{2} \mathrm{~g}^{-1}, 0.088 \mathrm{~g} \mathrm{~cm}^{-3}$ and $99.9 \%$, respectively. 


\subsection{Materials for the electrochemical pre-treatment}

Electrochemical pretreatment, in continuous system, was performed in a home-made flow cell [35]. Two interconnected PAPYEX carbon papers supplied by Mersen (France) were used as counter-electrodes $(85 \mathrm{~mm} \times 85 \mathrm{~mm})$ and compartments were separated by cationic exchange membranes (Ionac 3470 - Lanxess SAS, Courbevoie, France). The reference electrode (Saturated Calomel Electrode - SCE) was positioned in the middle of the graphite felt $(48 \mathrm{~mm}$ diameter and $12 \mathrm{~mm}$ width) and the potential control was performed using a potentiostat (Princeton Applied Research, EG\&G 362). To ensure a good homogeneity of the potential distribution in the three dimensional working electrode, the felt was located between the two counter-electrodes [35]. The cell was thoroughly rinsed with distilled water before and after each experiment. The solution (100 $\mathrm{mg} \mathrm{L}^{-1} \mathrm{MNZ}$ in aqueous acidic medium $\left.\mathrm{H}_{2} \mathrm{SO}_{4} 1 \mathrm{~N}\right)$ percolated the porous electrode at various flow rates monitored by a Gilson minipuls 2 peristaltic pump (Middleton, WI, USA).

\subsection{Biological treatment}

Activated sludge obtained from a local wastewater treatment plant (Rennes Beaurade, France) was used in this study. It was washed at least five times with water and centrifuged at 3000 rpm for 10 min to remove

any residual carbon and mineral source. Cultures were carried out at least in duplicates at $25^{\circ} \mathrm{C}$ in $250 \mathrm{~mL}$ erlenmeyer flasks containing $100 \mathrm{~mL}$ of medium with $0.5 \mathrm{~g} \mathrm{~L}^{-1}$ of activated sludge. The following mineral basis was used for all experiments $\left(\mathrm{g} \mathrm{L}^{-1}\right)$ : $\mathrm{Na}_{2} \mathrm{HPO}_{4} 2 \mathrm{H}_{2} \mathrm{O}$, 33.4; $\mathrm{KH}_{2} \mathrm{PO}_{4}, 8.5, \mathrm{~K}_{2} \mathrm{HPO}_{4}, 20.8, \mathrm{MgSO}_{4} .7 \mathrm{H}_{2} \mathrm{O}, 22.5 ; \mathrm{CaCl}_{2}, 27.6 ; \mathrm{FeCl}_{3}, 0.26$ and $\mathrm{NH}_{4} \mathrm{Cl}$, 
$75 \mathrm{mg} \mathrm{L}^{-1}$. The $\mathrm{pH}$ was then adjusted to 7.0 with $\mathrm{NaOH}$ solution. Sample $(5 \mathrm{~mL})$ were taken every 2 or 3 days and filtered on $0.45 \mu \mathrm{m}$. pH measurements were carried out using a Hanna pHmetre with a combined micro-electrode probe (thermo Spectronic, Rochester, USA).

\subsection{Analytical Procedure}

\subsubsection{Electrochemical Analysis}

Electrochemical analysis of MNZ and electrolyzed solutions were performed using a conventional three electrode-cell with a glassy carbon electrode $\left(7 \mathrm{~mm}^{2}\right)$ as working electrode, a platinum wire as counter electrode and a saturated calomel electrode (SCE) as reference electrode. Experiments were performed at room temperature under nitrogen atmosphere. Voltammograms were obtained using a versaSTAT3 AMETEK Model (Princeton Applied Research) potentiostat/galvanostat. Before each experiment, the glassy carbon electrode was thoroughly polished with Struers waterproof silicon carbide paper.

\subsubsection{High Performance Liquid Chromatography (HPLC)}

MNZ concentration was determined by HPLC using a Waters 996 system equipped with waters 996 PDA (Photodiode Array Detector) and Waters 600 LCD Pump. The separation was achieved on a Waters $\mathrm{C}-18(5 \mu \mathrm{m} ; 4.6 \times 250 \mathrm{~mm})$ reversed-phase and the mobile phase consisted of a mixture of acetonitrile / ultra-pure water $(20$ / 80, v / v) and $0.1 \%$ Formic acid. The flow rate was set at $1 \mathrm{~mL} \mathrm{~min}^{-1}$ and $10 \mu \mathrm{L}$ injections were used. Detection of MNZ was carried out at $318 \mathrm{~nm}$ and the retention time was approximately $4.3 \mathrm{~min}$. Before HPLC analysis, the $\mathrm{pH}$ of the electrolyzed solutions should be raised at 3 .

\subsubsection{UPLC-MS / MS method}




\section{Ultra-pressure liquid chromatography}

The devices used are detailed in previous works [25]. The analytes were separated by a Waters Acquity UPLC system (Waters corporation, Milford, MA, USA) consisting of an Acquity UPLC binary solvent manager, an Acquity UPLC sample manager and an Acquity UPLC column heater equipped with a Waters Acquity UPLC BEH C18 column $(2.1 \mathrm{~mm} \times$ $100 \mathrm{~mm}, 1.7 \mu \mathrm{m}$ particle size) (Milford, MA, USA). Gradient LC elution was performed with $0.1 \%$ formic acid in acetonitrile as mobile phase A and ultrapure water added $0.1 \%(\mathrm{v} / \mathrm{v})$ of formic acid as mobile phase B. Separation of the analytes on the column was performed with a gradient of phase $\mathrm{A} /$ phase $\mathrm{B}$ at $0.4 \mathrm{~mL} \mathrm{~min}{ }^{-1}$ flow rate. The starting eluent composition consisted of $10 \%$ phase A which was then linearly increased to reach $91 \%$ at 6 min.

\section{Tandem mass spectrometry}

The separated compounds were detected with a Waters Micromass Quattro Premier (Waters Corporation, Manchester, UK) triple quadripole mass spectrometer. It was operated with an electrospray source in positive ionization mode with a cone potential of $20 \mathrm{~V}$. The ionization source conditions were: capillary voltage of $3 \mathrm{kV}$, source temperature $120^{\circ} \mathrm{C}$ and desolvation temperature $350^{\circ} \mathrm{C}$. The cone and desolvation gas flows $\left(\mathrm{N}_{2}\right)$ were 50 and $750 \mathrm{~L} \mathrm{~h}^{-1}$, respectively. Analyses were performed in full scan mode. Spectra were acquired between 60 and $300 \mathrm{~m} / \mathrm{z}$ and the data were treated with Micromass MassLynx 4.1 software.

\subsubsection{Total Organic Carbon (TOC) and total nitrogen measurements}

TOC and total nitrogen were measured by means of a $\mathrm{TOC}-\mathrm{V}_{\mathrm{CPH} / \mathrm{CPN}}$ Total Organic Analyzer Schimadzu. $\mathrm{HCl}(2 \mathrm{~N})$ and $\mathrm{H}_{3} \mathrm{PO}_{4}(25 \%)$ were considered for $\mathrm{CO}_{2}$ and $\mathrm{NO}$ production. Organic carbon compounds were combusted and converted to $\mathrm{CO}_{2}$, which was detected and measured by a non-dispersive infrared detector (NDIR), TOC values were always obtained 
using the standard NPOC (Non Purgeable Organic Carbon) method. Dissolved nitrogen compounds were combusted and converted to NO which was then mixed with ozone chemiluminescence for detection by a photomultiplier. For each sample, each measurement was triplicated.

\subsubsection{Chemical Oxygen Demand (COD) measurements}

Chemical Oxygen Demand was measured as previously reported [28]. For each sample, each measurement was doubled or triplicated.

\subsubsection{Biological Oxygen Demand (BOD 5 ) measurements}

Biodegradability was deduced from $\mathrm{BOD}_{5}$ measurements, as previously reported [28].

Before use, $\mathrm{NaOH}$ was added to achieve neutral $\mathrm{pH}(7.0 \pm 0.2)$. Similar protocol was also considered for the blank solution, for which the sample was replaced by water to deduce the biological oxygen demand corresponding to the endogenous respiration. For each sample, each measurement was doubled or triplicated.

\section{Results and discussion}

\subsection{Electroreduction of metronidazole in aqueous acidic medium}

Several analytical studies on the electroreduction of metronidazole have been published. The reduction of MNZ is a complex process, since the mechanism of nitro group reduction depends significantly on the nature of the electrode and the medium (solvents, the supporting electrolyte and $\mathrm{pH})$ [36-41]. The authors reported that metronidazole is reducible to the corresponding amine in acidic medium using a mercury electrode. The first step is a 
four-electron reduction of the nitro group into hydroxylamine (Eq. 1) and the second one involves a subsequent two-electron reduction into the amine derivative (Eq. 2) [39].

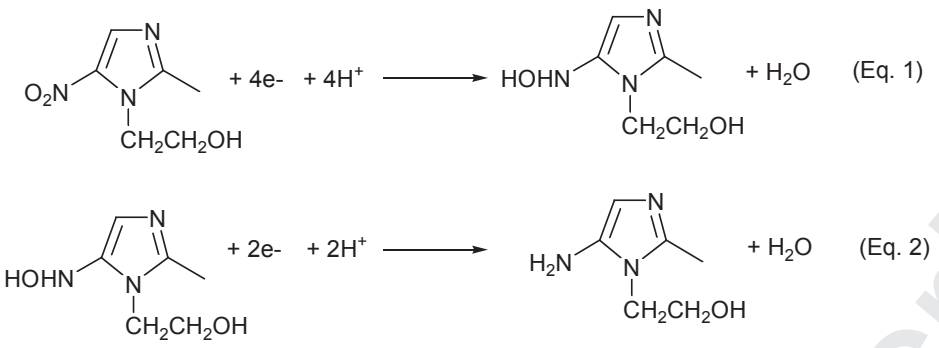

In this work, cyclic voltammetry was used to investigate the electrochemical reduction of MNZ $\left(1 \mathrm{~g} \mathrm{~L}^{-1}\right)$ on a glassy carbon electrode in acidic aqueous medium $\mathrm{H}_{2} \mathrm{SO}_{4}(0.5 \mathrm{M})$. The voltammogram showed a single reduction peak of MNZ (Fig. 2). This peak corresponded to the four-electrons reduction of the nitro group to the corresponding hydroxylamine according to the currently accepted mechanism for the electroreduction of aromatic and heteroaromatic nitro compounds [40, 41].

The voltammogram did not show a peak corresponding to the complete reduction of the nitro group into amine derivatives (6 electrons), since hydrogen evolution occurred on glassy carbon electrode just before the reduction of R-NHOH into $\mathrm{R}^{-\mathrm{NH}_{2}}$. 


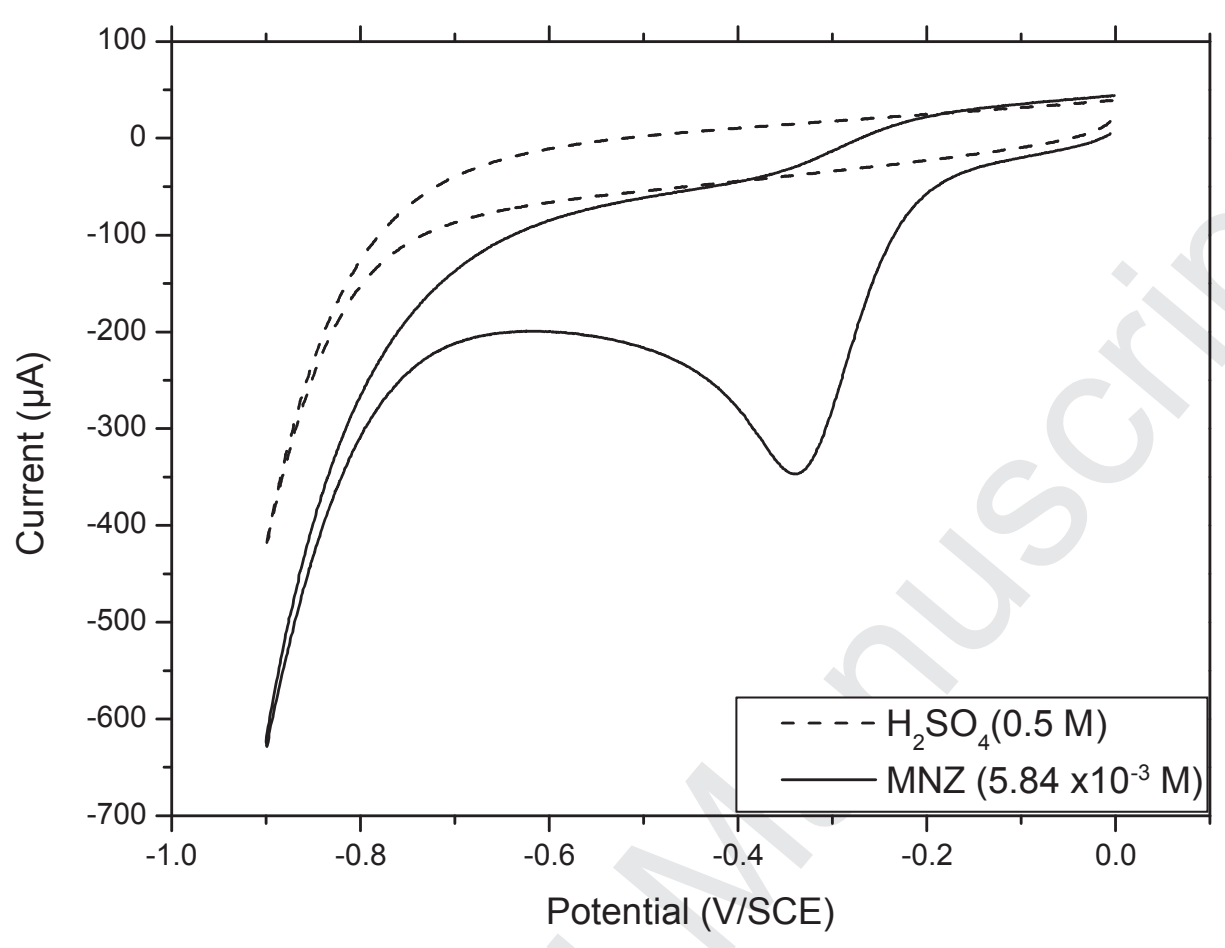

Fig. 2. Cyclic voltammetry of MNZ solution $\left(1 \mathrm{~g} \mathrm{~L}^{-1}\right)$. Voltammograms were recorded at 100 $\mathrm{mV} \mathrm{s}^{-1}$ in $\mathrm{H}_{2} \mathrm{SO}_{4}(0.5 \mathrm{M})$ on a glassy carbon electrode $\left(7 \mathrm{~mm}^{2}\right)$, under nitrogen atmosphere.

\subsection{Direct Electrolysis}

Nitrocompound can usually be reduced into their corresponding amines at potentials lower than $-1 \mathrm{~V} / \mathrm{SCE}$ on carbon electrodes in aqueous acidic medium [42]. Thus, cathodic reduction of MNZ $\left(100 \mathrm{mg} \mathrm{L}^{-1}\right)$ were carried out at $-1.2 \mathrm{~V} / \mathrm{SCE}$ in the flow electrochemical cell, at a flow rate of $1 \mathrm{~mL} \mathrm{~min}$. Since the hydroxylamine intermediate is very reactive and usually leads to dimers, we tried to obtain the amino product by using very cathodic potential to enhance biodegradability. 
After a single pass through the flow cell, the voltammogram of the electrolyzed solution showed the disappearance of the signal related to MNZ reduction (Fig. 3). The voltammogram did not show any signal corresponding to by-products formed during electrolysis.

This result confirmed therefore the reduction of $\mathrm{MNZ}$ and showed the absence of electroactive products after electrolysis in the studied potential range.

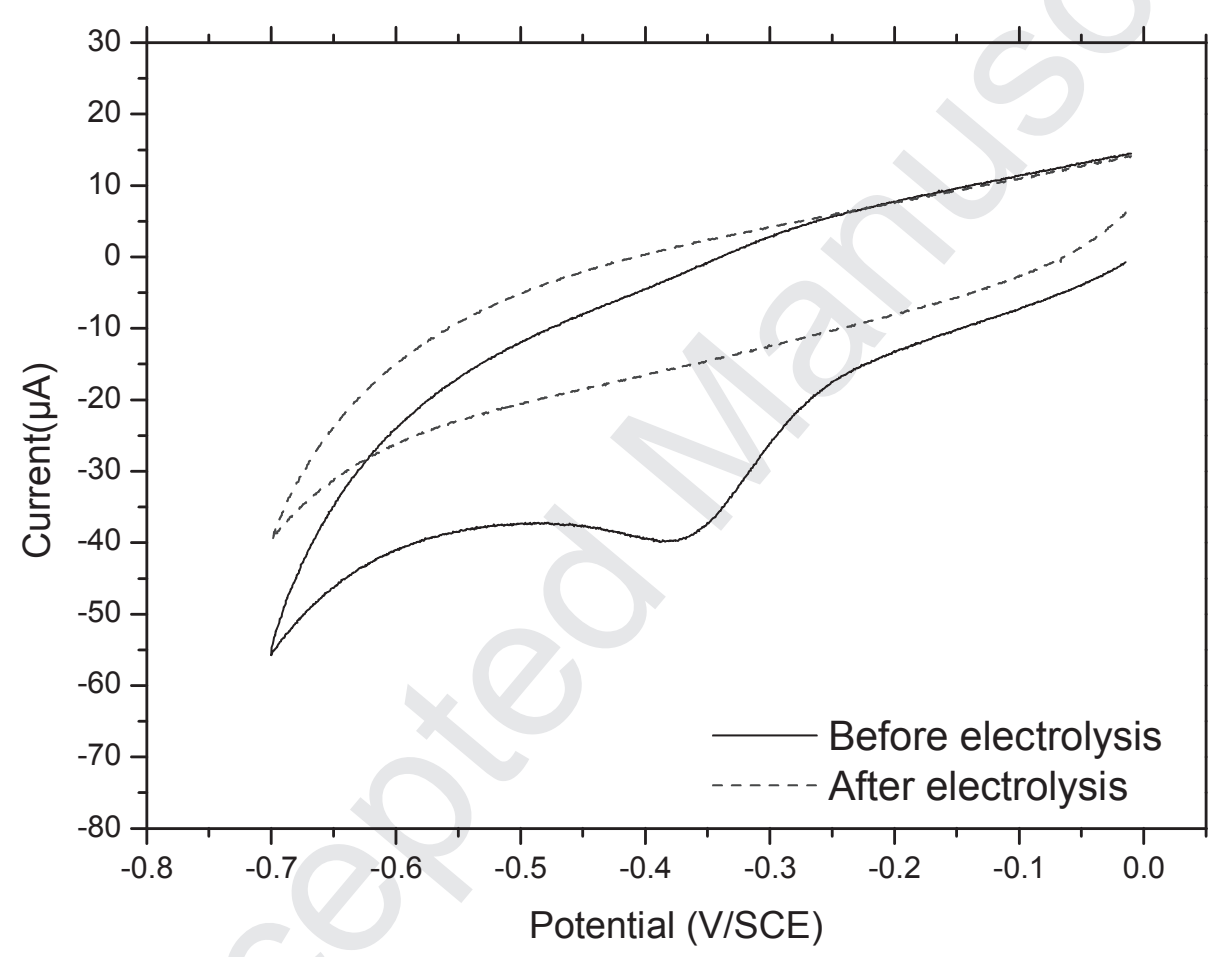

Fig. 3. Cyclic voltammetry of MNZ solution $\left(100 \mathrm{mg} \mathrm{L}^{-1}\right)$ before (- ) and after (- - ) electrolysis in the flow cell at $-1.2 \mathrm{~V} / \mathrm{SCE}$. Voltammograms were recorded at $100 \mathrm{mV} \mathrm{s}^{-1}$ in $\mathrm{H}_{2} \mathrm{SO}_{4}(0.5 \mathrm{M})$ on a glassy carbon electrode $\left(7 \mathrm{~mm}^{2}\right)$, under nitrogen atmosphere.

\subsubsection{MNZ degradation}

Electrolyzed solutions were analyzed by HPLC to measure the residual concentration of MNZ. HPLC analysis showed a total disappearance of the MNZ (conversion yield > 99.9\%) after one pass through the flow-cell, showing that the recycling of the solution was not 
necessary. This result confirmed cyclic voltammetry analyses and the complete reduction of MNZ at the graphite felt electrode.

After electrolysis, the solution was also analyzed by UPLC-MS/MS. Comparaison with a blank performed in the same conditions but without MNZ showed the presence of three main by-products that we were able to identify at $0.64\left(\mathrm{MH}^{+} 143.7\right), 0.71\left(\mathrm{MH}^{+} 295.1\right)$ and 0.88 $\min \left(\mathrm{MH}^{+}\right.$279.1). The first one corresponds to the expected product 2 resulting from the reduction of nitro group into amine (Scheme 1).

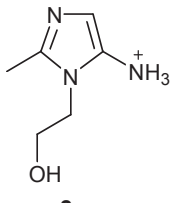

2

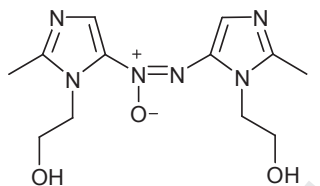

3

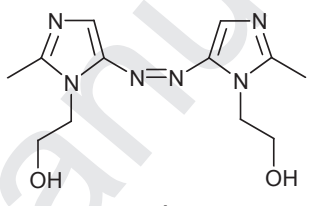

4

Scheme 1: Chemical structures of identified degradation by-products.

The peaks at $0.71 \mathrm{~min}$ and $0.88 \mathrm{~min}$ seem to correspond to the formation of the dimers $\mathbf{3}$ and 4. Indeed, if the reduction of the nitro group is not complete, the hydroxylamine intermediate is formed; it can be then oxidized at atmosphere into a nitroso compound, which can react with another hydroxylamine to give the azoxy species $\mathbf{3}$ or with $\mathbf{2}$ to give the azo compound $\mathbf{4}$ [42].

\subsubsection{Total organic carbon (TOC) analyses}

Mineralisation was examined for MNZ (100 $\left.\mathrm{mg} \mathrm{L}^{-1}\right)$ and a solution electrolyzed for

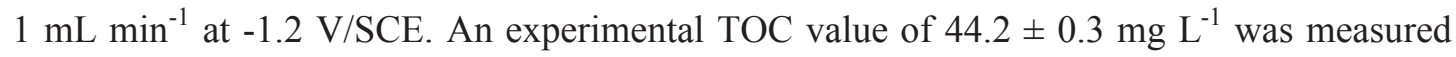
for non-treated MNZ (100 mg L $\left.\mathrm{m}^{-1}\right)$. This value was in accordance with the theoretical one, $42.11 \mathrm{mg} \mathrm{L}^{-1}$, calculated using the molecular formula of MNZ, $(12.01 \times 6) / 171.1$. The evolution of TOC during the pretreatment is reported in table 2. 
Although, MNZ was completely degraded after reduction, the mineralization yield remained low since a decrease of only $14.5 \pm 1.4 \%$ was observed after MNZ reduction. This low mineralization yield was a favorable condition for the proposed combined process since the aim of the electrochemical pretreatment was not to mineralize the effluent, as usually observed when advanced oxidation processes are implemented, but to increase the biodegradability of the solution. By-products are expected to be biologically assimilable by microorganisms from activated sludge and hence used as carbon sources during the subsequent biological treatment.

\subsubsection{Total nitrogen measurements}

The total nitrogen (TN) was measured to check for possible cleavage of the C-N bonds of MNZ during electrolysis. As observed in table 2 only a weak decrease of the TN value was observed showing that the electrochemical treatment did not promote high nitrogen release in the medium. MNZ degradation did not therefore lead to an important elimination of carbon or nitrogen from the molecule, which is in accordance with a simple reduction of the $\mathrm{NO}_{2}$ group.

\subsubsection{Biodegradability evaluation}

In order to assess the biodegradability, $\mathrm{BOD}_{5}$ and $\mathrm{COD}$ values were measured before and after electrolysis and the $\mathrm{BOD}_{5} / \mathrm{COD}$ ratio was used as a biodegradability indicator. Indeed, an effluent can be considered as easily biodegradable if its $\mathrm{BOD}_{5} / \mathrm{COD}$ ratio is above 0.4 [43, 44].

The $\mathrm{BOD}_{5} / \mathrm{COD}$ ratio of $\mathrm{MNZ}\left(100 \mathrm{mg} \mathrm{L}^{-1}\right)$ was 0.07 , confirming the biorecalcitrance of the target compound. As seen in table 2 , the $\mathrm{BOD}_{5} / \mathrm{COD}$ ratio increased to $0.20 \pm 0.07$ after electrolysis indicating a good conversion of MNZ to more biodegradable products, even if, the limit of biodegradability (0.4) was not achieved. 
Table 2: TOC, COD, Total nitrogen and biodegradability of MNZ (100 $\left.\mathrm{mg} \mathrm{L}^{-1}\right)$ and electrolyzed solution $\left(\mathrm{E}=-1.2 \mathrm{~V}, 1 \mathrm{~mL} \mathrm{~min}^{-1}\right)$.

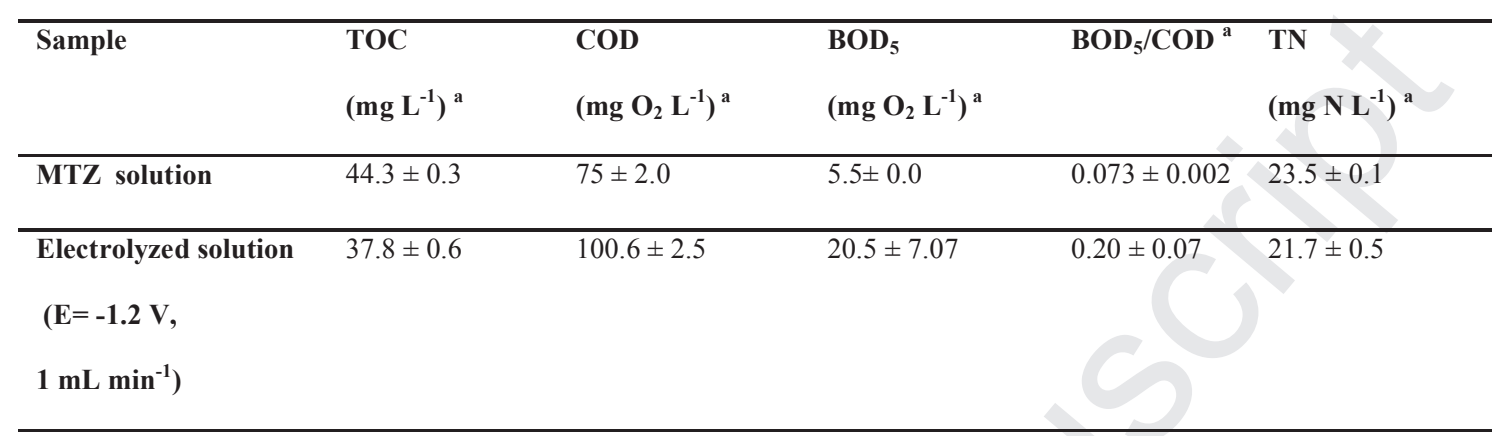

${ }^{\mathrm{a}}$ Uncertainties are based on two or three reproducibility measurements

\subsection{Indirect electroreduction of metronidazole}

In order to improve the selectivity of MNZ reduction, indirect electrolysis was performed with a titanocene complex used as catalyst in aqueous acidic medium.

\subsubsection{Catalytic activity of titanium complex}

The oxidized form of the mediator $\left(\mathrm{C}_{5} \mathrm{H}_{5}\right)_{2} \mathrm{TiOH}^{+}$was obtained by spontaneous hydrolysis of titanocene dichloride in $1 \mathrm{~N} \mathrm{H}_{2} \mathrm{SO}_{4}$ [45]. The complex $\left(\mathrm{C}_{5} \mathrm{H}_{5}\right)_{2} \mathrm{TiOH}^{+}$was then reduced electrochemically into its active form $\left(\mathrm{C}_{5} \mathrm{H}_{5}\right)_{2} \mathrm{Ti}^{+}[33,34]$, according to the following reaction: $\left(\mathrm{C}_{5} \mathrm{H}_{5}\right)_{2} \mathrm{TiOH}^{+}+\mathrm{e}^{-}+\mathrm{H}^{+} \longrightarrow\left(\mathrm{C}_{5} \mathrm{H}_{5}\right)_{2} \mathrm{Ti}^{+}+\mathrm{H}_{2} \mathrm{O} \quad$ (Eq. 3)

The catalytic activity of the titanium complex toward the MNZ reduction was studied by cyclic voltammetry in aqueous acidic medium (Fig. 4). A reversible system corresponding to $\mathrm{Ti}^{\mathrm{IV} / I I I}$ was observed by cyclic voltammetry at $-0.46 \mathrm{~V} / \mathrm{SCE}$. The catalytic activity of titanocene toward the reduction of metronidazole was shown by cyclic voltammetry. The addition of increasing concentrations of MNZ enhanced the reduction peaks, while the reverse anodic peak decreased. 


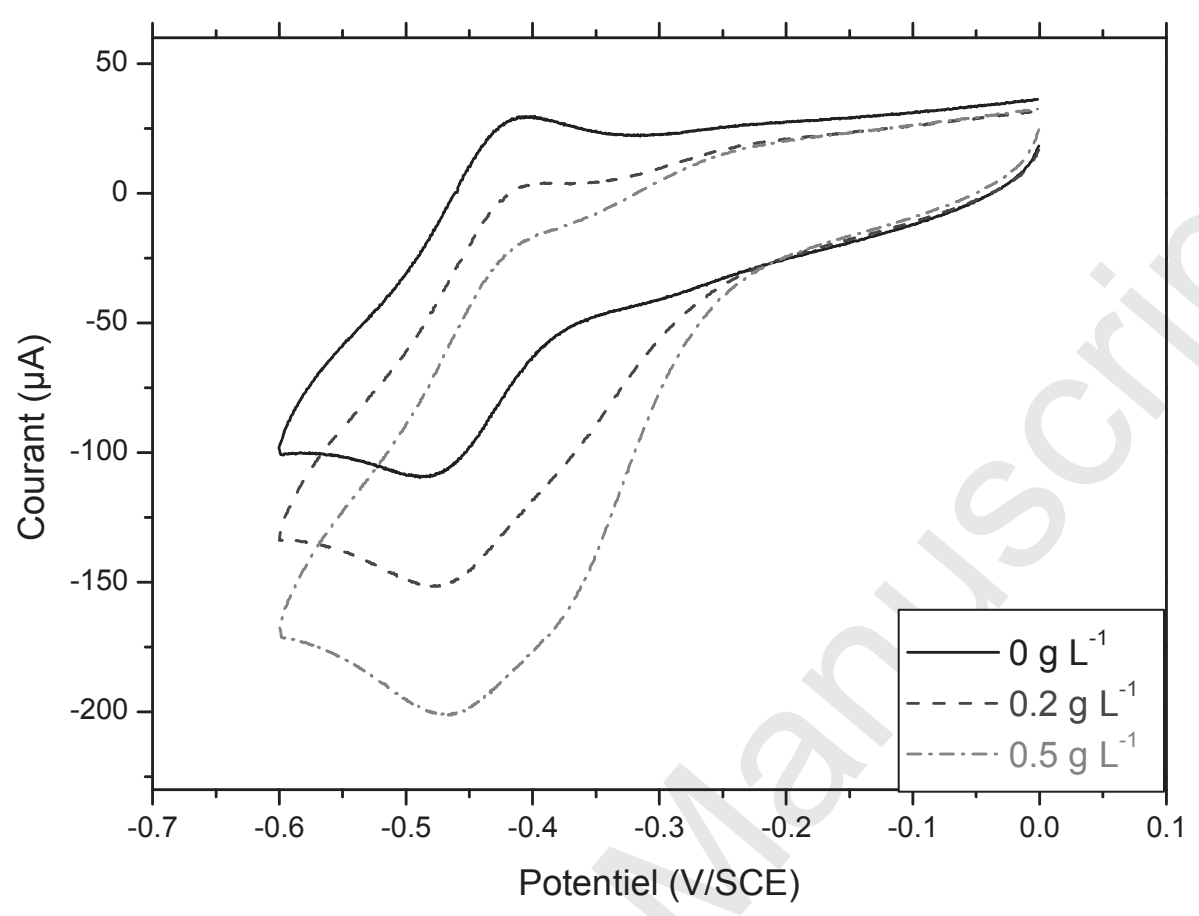

Fig. 4. Voltammograms of titanium complex $\left(1 \mathrm{~g} \mathrm{~L}^{-1}\right)$ recorded at $100 \mathrm{mV} \mathrm{s}^{-1}$ in aqueous acidic medium $\mathrm{H}_{2} \mathrm{SO}_{4}(0.5 \mathrm{M})$ in the absence (— $)$ and in the presence of $0.2 \mathrm{~g} \mathrm{~L}^{-1}$

$$
(---) \text { and } 0.5 \mathrm{~g} \mathrm{~L}^{-1}(-\cdot \cdot \cdot) \text { of MNZ. }
$$

\subsubsection{Degradation and mineralization of MNZ by indirect electrolysis}

Cathodic reduction of MNZ (100 $\left.\mathrm{mg} \mathrm{L}^{-1}\right)$ was performed at $-0.46 \mathrm{~V} / \mathrm{SCE}$ in the flow cell (1 $\left.\mathrm{mL} \mathrm{min}^{-1}\right)$, in aqueous acidic medium with titanocene at various concentrations $(10,20$ and 50 $\left.\mathrm{mg} \mathrm{L}^{-1}\right)$.

Cyclic voltammetry and HPLC analyses showed a total degradation of MNZ after a single pass through the flow cell (conversion yields $>99.9 \%$ ) for all concentrations of catalyst used. As with the direct electrolysis performed at $-1.2 \mathrm{~V} / \mathrm{SCE}$, UPLC-MS / MS analyses of the solution after reduction of MNZ $\left(100 \mathrm{mg} \mathrm{L}^{-1}\right)$ at $-0.46 \mathrm{~V} / \mathrm{SCE}$ in the presence of titanocene 
$\left(10 \mathrm{mg} \mathrm{L}^{-1}\right)$ revealed the presence of the amino derivative $\mathbf{2}$ and the azoxy and azo compound 3 and 4. These results show that even in the presence of titanocene direct electroreduction of MNZ on the electrode into hydroxylamine still occurred at $-0.46 \mathrm{~V} / \mathrm{SCE}$ and was in competition with the indirect reduction into amine.

Mineralization yields in the range of 12 to $27 \%$ were also estimated by TOC measurements after cathodic reduction of MNZ in the presence of 10, 20 and $50 \mathrm{mg} / \mathrm{L}$ catalyst. Even if the selectivity of the electroreduction toward the formation of the amino compound was not as good as expected, the mineralization yields remained low. Thus, the combination of an electrochemical treatment with a biological one remained of interest and should be confirmed through biodegradability assessment.

\subsubsection{Biodegradability tests}

The values of $\mathrm{COD}, \mathrm{BOD}_{5}$ and $\mathrm{BOD}_{5} / \mathrm{COD}$ obtained after the electrochemical pretreatment are given in Table 3.

The $\mathrm{BOD}_{5} / \mathrm{COD}$ ratio increased from 0.07 to $0.31,0.42$ and 0.23 for 10,20 and $50 \mathrm{mg} \mathrm{L}^{-1}$ catalyst, respectively. This improvement of biodegradability in the presence of titanocene suggests that although the same main by-products were detected by UPLC-MS / MS after direct and indirect electrolysis, indirect electroreduction with titanocene allowed the formation of more biodegradable by-products. A possible explanation would reside in the amount of dimers $\mathbf{3}$ and $\mathbf{4}$ formed during the electrochemical pretreatment; that can be different in the two electrolysis modes, suggesting the high selectivity of indirect electrolysis toward the formation of biodegradable by-products.

A high increase of the $\mathrm{BOD}_{5}$ / COD ratio (from 0.2 to 0.42 ) was obtained for MNZ solutions electrolyzed in the presence of $20 \mathrm{mg} \mathrm{L}^{-1}$ of $\left(\mathrm{C}_{5} \mathrm{H}_{5}\right)_{2} \mathrm{TiCl}_{2}$, the by-products formed being 
considered as biodegradables $\left(\mathrm{BOD}_{5} / \mathrm{COD}=0.42>0.4\right)$. Hence, an electrochemical reduction provides favorable conditions for subsequent biological treatment.

For MNZ solution electrolyzed in the presence of $50 \mathrm{mg} \mathrm{L}^{-1}$ of $\left(\mathrm{C}_{5} \mathrm{H}_{5}\right)_{2} \mathrm{TiCl}_{2}$, the $\mathrm{BOD}_{5} / \mathrm{COD}$ ratio $\left(\mathrm{BOD}_{5} / \mathrm{COD}=0.23\right)$ was similar to $\mathrm{MNZ}$ solution electrolyzed in the absence of titanocene. A possible explanation would be that the presence of titanocene at high concentration could affect the biodegradability trend.

Table 3: Effect of $\left(\mathrm{C}_{5} \mathrm{H}_{5}\right)_{2} \mathrm{TiCl}_{2}$ concentration on the biodegradability of the electrolyzed solutions. Electrolysis conditions $[\mathrm{MNZ}]=100 \mathrm{mg} \mathrm{L}^{-1}$, Flow rate: $1 \mathrm{~mL} \mathrm{~min}^{-1}$

\begin{tabular}{lccc}
\hline$\left[\left(\mathrm{C}_{5} \mathrm{H}_{5}\right)_{2} \mathrm{TiCl}_{2}\right]\left(\mathrm{mg} \mathrm{L}^{-1}\right)$ & $\mathrm{BOD}_{5}\left(\mathrm{mg} \mathrm{O}_{2} \mathrm{~L}^{-1}\right)^{\mathrm{a}}$ & $\mathrm{COD}\left(\mathrm{mg} \mathrm{O}_{2} \mathrm{~L}^{-1}\right)^{\mathrm{a}}$ & $\mathrm{BOD}_{5} / \mathrm{COD}^{\mathrm{a}}$ \\
\hline 0 & $20.5 \pm 7.07$ & $100.6 \pm 2.50$ & $0.20 \pm 0.07$ \\
\hline 10 & $37 \pm 7.07$ & $119 \pm 1.41$ & $0.31 \pm 0.06$ \\
\hline 20 & $76 \pm 7.07$ & $182 \pm 4.24$ & $0.42 \pm 0.04$ \\
\hline 50 & $35 \pm 4.24$ & $147.5 \pm 0.70$ & $0.23 \pm 0.03$
\end{tabular}

${ }^{\mathrm{a}}$ Uncertainties are based on two or three reproducibility measurements

\subsection{Biological treatment}

In order to confirm these encouraging results, activated sludge culture of pure MNZ solution and electrolyzed solutions in the absence and in the presence of $10 \mathrm{mg} \mathrm{L}^{-1}$ and $20 \mathrm{mg} \mathrm{L}^{-1}$ of $\mathrm{Cp}_{2} \mathrm{TiCl}_{2}$ were performed.

The first step in the biological treatment consists to check the biosorption on activated sludge of MNZ and by-products from MNZ reduction. Since, it is a rapid phenomenon, biosorption can be observed within few hours. Thus, measurements of TOC and residual MNZ concentration were monitored during the first 2 hours of activated sludge culture on pure MNZ and the electrolyzed solutions (Fig. 5). 
As observed, TOC values and the residual MNZ concentrations remained stable during the first 2 hours of experiments, showing that neither MNZ nor its by-products were biosorbed on activated sludge. 

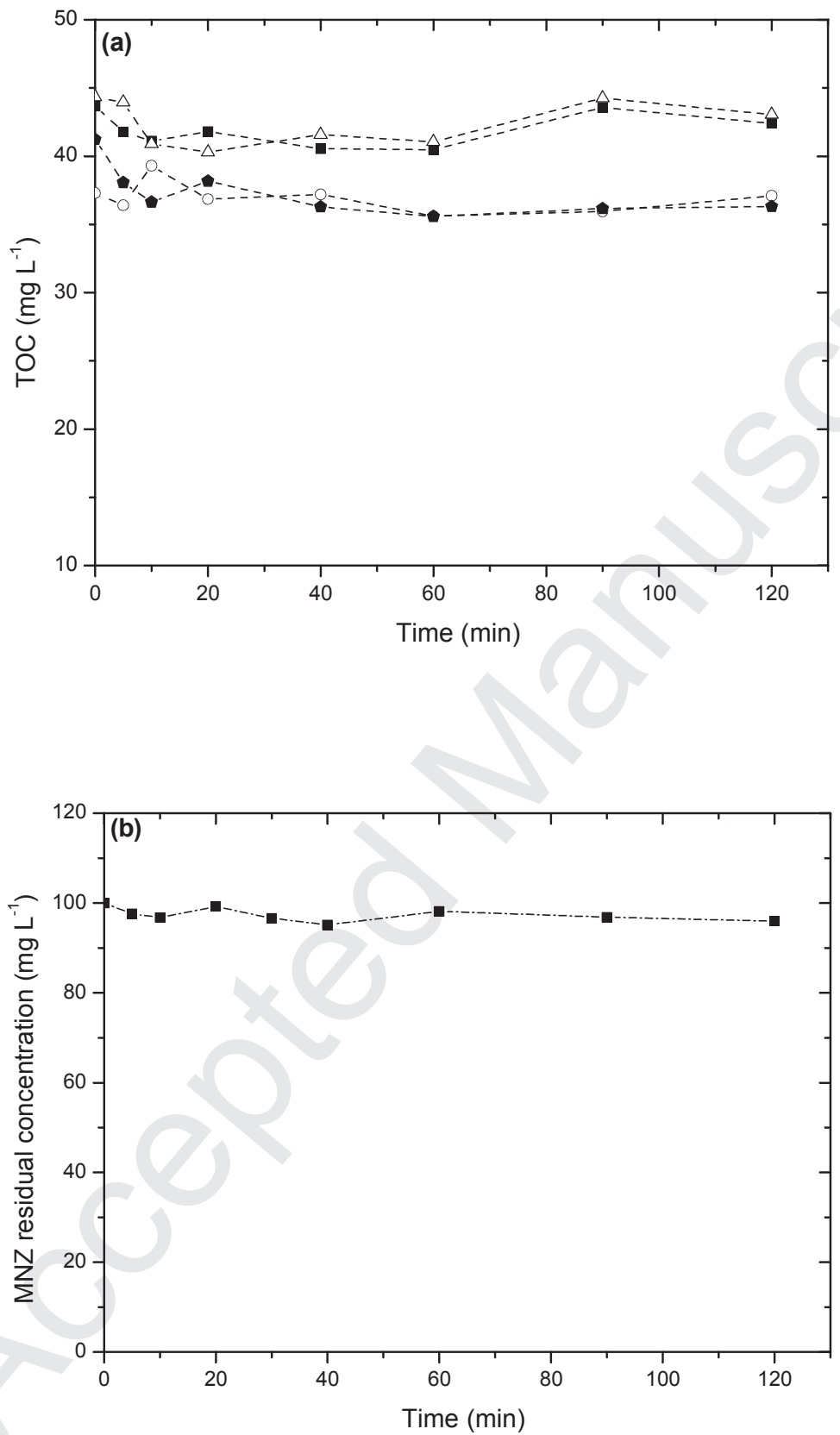

Fig. 5. Time-courses of the TOC values (a) and residual MNZ concentrations (b) during biosorption on activated sludge $\left(0.5 \mathrm{~g} \mathrm{~L}^{-1}\right)$ of MNZ $\left(100 \mathrm{mg} \mathrm{L}^{-1}\right)(----)$, and MNZ solutions electrolyzed in the absence $\left({ }^{--^{-}}\right)$and in the presence of $10 \mathrm{mg} \mathrm{L}^{-1}\left(\cdots^{-\cdot}\right)$ and $20 \mathrm{mg} \mathrm{L}^{-1}$ ( - - $)$ of $\left(\mathrm{C}_{5} \mathrm{H}_{5}\right)_{2} \mathrm{TiCl}_{2}$. 
Biological treatments were then carried out by means of activated sludge. Several parameters such as MNZ concentration, TOC and $\mathrm{pH}$ were monitored during the 24 days of culture.

Time-course of the MNZ concentration during the biological treatment of pure non-pretreated MNZ is displayed in Fig. 6, showing only a weak decrease of its concentration during culture (around 15\%), characteristic of its recalcitrance. As displayed in Fig. 7, TOC measurements confirmed HPLC results, since the level of mineralization remained low during the bacterial culture.

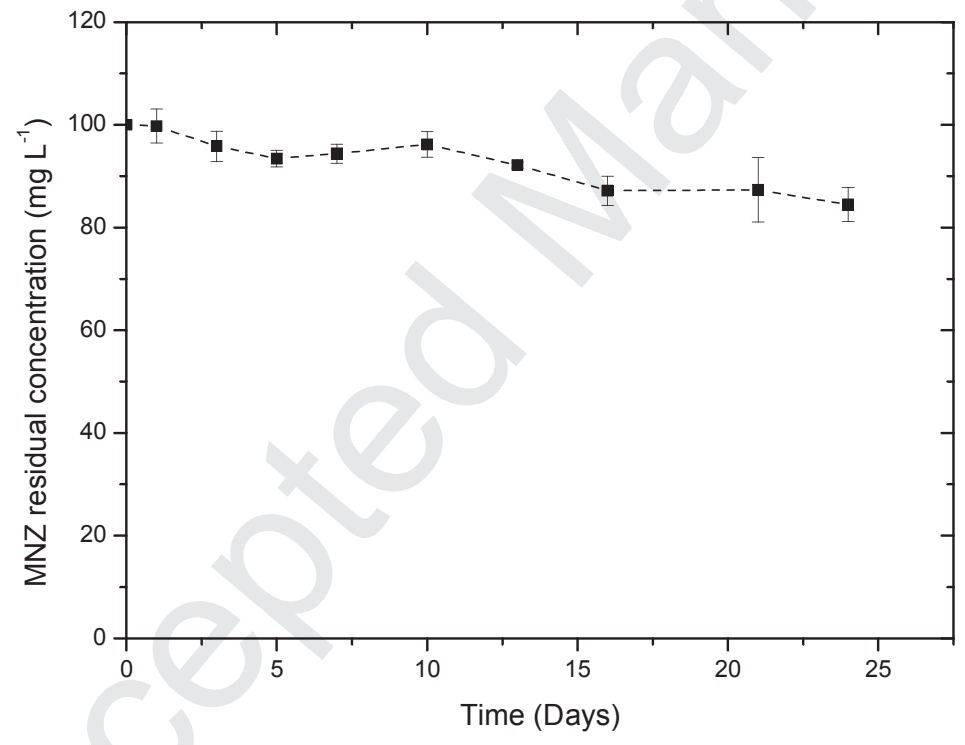

Fig. 6. MNZ concentration time-course during activated sludge culture on non-pretreated MNZ solution. Error bars are based on 3 reproducibility measurements

Contrarily, an improvement of the mineralization yield was clearly observed during the biological treatment of the electrolyzed solutions, showing the relevance of the electroreduction pretreatment of metronidazole prior to a biological process (Fig.7). 
After direct electrolysis, evolution of mineralization showed an increase until 13 days; $55.3 \pm$ $0.14 \%$ of the carbon was mineralized. From day 13 to the end of culture after 24 days no further TOC decrease was observed, showing that the residual by-products were non biodegradable. This observation illustrated an assimilation of some of the degradation products, in agreement with the corresponding increase of the $\mathrm{BOD}_{5} / \mathrm{COD}$ ratio values (from 0.07 to 0.2$)$.

In the presence of titanocene, a significant reduction of the TOC was recorded within 16 days of culture, $62.1 \pm 7.0 \%$ and $66.3 \pm 5.4 \%$ TOC removal were obtained for the electrolyzed solution in the presence of 20 and $10 \mathrm{mg} \mathrm{L}^{-1}$ of $\left(\mathrm{C}_{5} \mathrm{H}_{5}\right)_{2} \mathrm{TiCl}_{2}$ respectively, showing a good assimilation of the reduced by-products by microorganisms. This positive trend appeared more pronounced if the contribution of titanocene, which was most likely recalcitrant, was not taken into account in the TOC amounts. Indeed, and owing to the carbon content of titanocene (48.2\%), initial and final TOC values were 33.4 and $6.7 \mathrm{mg} \mathrm{L}^{-1}$ for $20 \mathrm{mg} \mathrm{L}^{-1}\left(\mathrm{C}_{5} \mathrm{H}_{5}\right)_{2} \mathrm{TiCl}_{2}$ and 39.8 and 10.2 for $10 \mathrm{mg} \mathrm{L}^{-1}\left(\mathrm{C}_{5} \mathrm{H}_{5}\right)_{2} \mathrm{TiCl}_{2}$, respectively. Mineralization yields were 80.1 and $74.3 \%$ for 20 and $10 \mathrm{mg} \mathrm{L}^{-1}$ of $\left(\mathrm{C}_{5} \mathrm{H}_{5}\right)_{2} \mathrm{TiCl}_{2}$, respectively. From this and if the initial TOC values after subtracting the titanocene amount were considered, 46.4 and $45.8 \mathrm{mg} \mathrm{L}^{-1}$, overall mineralization yields resulting from the combined process can be determined and were found to be 85 and $78 \%$ in the presence of 20 and $10 \mathrm{mg} \mathrm{L}^{-1}$ of titanocene, respectively. After 16 days, no further significant mineralization was observed; TOC values remained nearly constant until the end of cultures. If compared to electrolysis pretreatment in the absence of titanocene, an improvement of biodegradability was therefore observed. It should also be noticed that mineralization yields observed during biological treatment and biodegradability deduced from $\mathrm{BOD}_{5} / \mathrm{COD}$ ratio followed the same trend, since both increased with the amount of catalyst in the medium, $0<10<20 \mathrm{mg} \mathrm{L}^{-1}\left(\mathrm{C}_{5} \mathrm{H}_{5}\right)_{2} \mathrm{TiCl}_{2}$. It should however be noted that to examine the relevance of indirect electroreduction, the 
catalyst was considered in solution in this study; while its immobilization on the electrode surface is the final objective of the proposed electrolytic pretreatment, therefore without any contribution to the TOC amount.

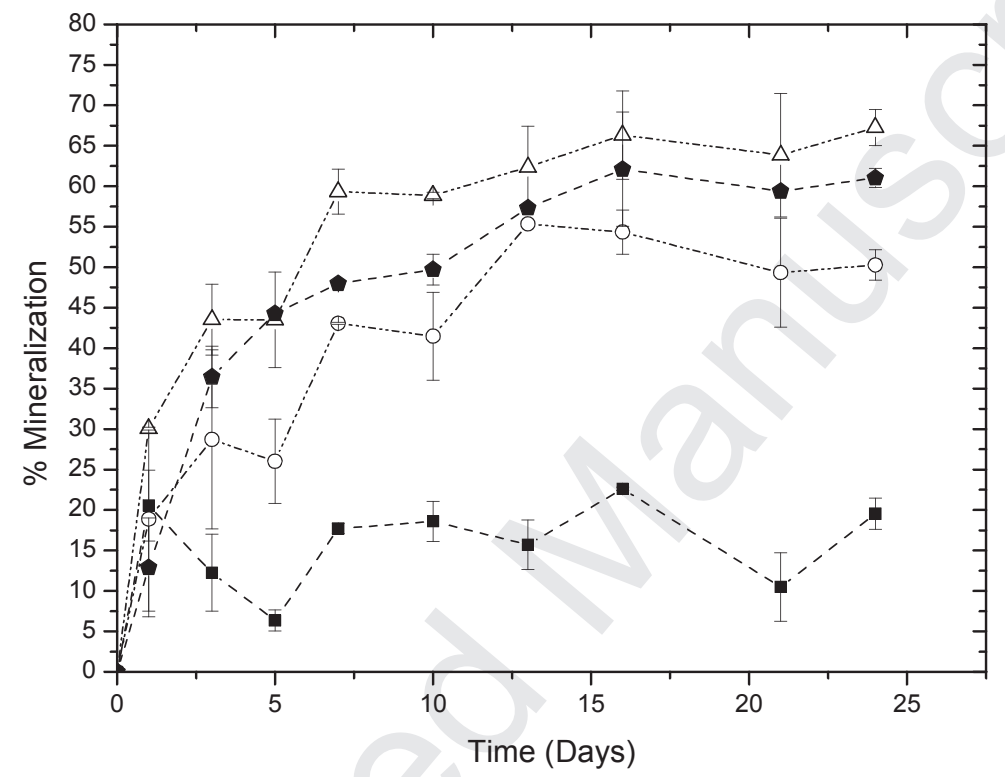

Fig. 7. Time-course of mineralization during activated sludge culture on MNZ solution (100

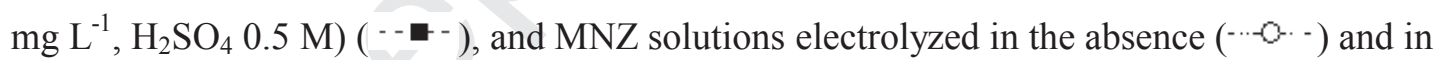
the presence of $10 \mathrm{mg} \mathrm{L}^{-1}(\cdots-\cdots)$ and $20 \mathrm{mg} \mathrm{L}^{-1}(-\cdots)$ of $\left(\mathrm{C}_{5} \mathrm{H}_{5}\right)_{2} \mathrm{TiCl}_{2}$. Error bars are based on 2 reproducibility measurements

\section{Conclusion}

This study showed the feasibility of coupling an electroreduction process with a biological treatment for the degradation of metronidazole, a bio-recalcitrant antibiotic. 
Metronidazole reduction was achieved either directly to the electrode or in the presence of titanocene. A total degradation of metronidazole was obtained, while the mineralization yields remained limited. Titanocene had a significant effect on the biodegradability trend, since indirect electrolysis seems to offer higher selectivity than direct electrolysis for the formation of more biodegradable by-products. The $\mathrm{BOD}_{5} / \mathrm{COD}$ ratio increased from 0.2 after direct electrolysis to 0.31 and 0.42 after reduction with 10 and $20 \mathrm{mg} \mathrm{L}^{-1}$ of titanocene, respectively. This enhancement of biodegradability was confirmed during the biological treatment, since mineralization yields of the electrolyzed solutions increased significantly. $85 \%$ of total organic carbon TOC was removed by means of the combined process, coupling the electroreduction in the presence of $10 \mathrm{mg} \mathrm{L}^{-1}$ of titanocene and a biological treatment. Therefore, pretreatment by indirect electrolysis improved significantly the mineralization yield (only $19.6 \%$ in the absence of pretreatment) and thus reduced the processing time of the biological treatment.

To improve these encouraging results, the immobilization of titanocene on the electrode surface should be subsequently investigated, to avoid direct reduction of MNZ on the electrode, leading to the formation of azo and azoxy dimers and to avoid possible pollution of the solution by the catalyst.

\section{Supporting information}

HPLC profile and mass spectrometry spectra of by-products are shown in the Appendice. 


\section{References}

[1] F. P. Tally, C. E. Sullivan, Metronidazole: In Vitro Activity, Pharmacology and Efficacy in Anaerobic Bacterial Infections, Pharmacotherapy 1 (1981) 28-38.

[2] Z. Fang, J. Chen, X. Qiu, X. Qiu, W. Cheng, L. Zhu, Effective removal of antibiotic metronidazole from water by nanoscale zero-valent iron particles, Desalination 268 (2011) 60-67.

[3] A. Bendesky, D. Menéndez, P. Ostrosky-Wegman, Is metronidazole carcinogenic?, Mutat. Res. 511 (2002) 133-144.

[4] R. F. Dantas, O. Rossiter, A. K. R. Teixeira, A. S. M. Simoes, V. L. da Silva, Direct UV photolysis of propranolol and metronidazole in aqueous solution, Chem. Eng. J. 158 (2010) 143-147.

[5] E. Vulliet, C. Cren-Olivé, Screening of pharmaceuticals and hormones at the regional scale, in surface and groundwaters intended to human consumption, Environ. Pollut. 159 (2011) 2929-2934.

[6] P. F. Lanzky, B. Halling-Serensen, The toxic effect of the antibiotic metronidazole on aquatic organisms, Chemosphere 35 (1997) 2553-2561.

[7] M. L. Richardson, J. M. Bowron, The fate of pharmaceutical chemicals in the aquatic environment, J. Pharm. Pharmacol. 37 (1985) 1-12.

[8] K. Kummerer, A. Al-Ahmad, V. Mersch-Sundermann, Biodegradability of some antibiotics, elimination of the genotoxicity and affection of wastewater bacteria in a simple test, Chemosphere 31 (2000) 701-710.

[9] J. D. Méndez-Díaz, G. Prados-Joya, J. Rivera-Utrilla, R. Leyva-Ramos, M. Sánchez-Polo, M. A. Ferro-García, N. A. Medellín-Castillo, Kinetic study of the adsorption of 
nitroimidazole antibiotics on activated carbons in aqueous phase, J. Colloid Interface Sci. 345 (2010) 481-490.

[10] J. Rivera-Utrilla, G. Prados-Joya, M. Sanchez-Polo, M. A. Ferro-Garcia, I. BautistaToledo, Removal of nitroimidazole antibiotics from aqueous solution by adsorption/bioadsorption on activated carbon, J. Hazard. Mater. 170 (2009) 298-305.

[11] F. Ingerslev, B. Halling-Sorensen, Biodegradability of metronidazole, olaquindox, and tylosin and formation of tylosin degradation products in aerobic soil-manure slurries, Ecotoxicol. Environ. Saf. 48 (2001) 311-320.

[12] F. Ingerslev, L. Torang, M. L. Loke, B. Hallig-Suensen, N. Nyholm, Primary biodegradation of veterinary antibiotics in aerobic and anaerobic surface water simulation systems, Chemosphere 44 (2001) 865-872.

[13] M. Sanchez-Polo, J. Rivera-Utrilla, G. Prados-Joya, M. A. Ferro-Garc1'a, I. BautistaToledo, Removal of pharmaceutical compounds, nitroimidazoles, from waters by using the ozone/carbon system, Water Res. 42 (2008) 4163-4171.

[14] G. Prados-Joya, M. Sanchez-Polo, J. Rivera-Utrilla, M. Ferro-garcia, Photodegradation of the antibiotics nitroimidazoles in aqueous solution by ultraviolet radiation, Water Res. 45 (2011) 393-404.

[15] H. Shemer, Y. K. Kunukcu, K. G. Linden, Degradation of the pharmaceutical Metronidazole via UV, Fenton and photo-Fenton processes, Chemosphere 63 (2006) 269276.

[16] H. Wang, G. Zhang, Y. Gao, Photocatalytic degradation of metronidazole in aqueous solution by niobate $\mathrm{K}_{6} \mathrm{Nb}_{10.8} \mathrm{O}_{30}$, Wuhan Univ. J. Nat. Sci. 15 (2010) 345-349.

[17] W. Cheng, M. Yang, Y. Xie, B. Linag, Z. Fang, E. P. Tsang, Enhancement of mineralization of metronidazole by the electro-Fenton process with a $\mathrm{Ce} / \mathrm{SnO}_{2}-\mathrm{Sb}$ coated titanium anode, Chem. Eng. J. 220 (2013) 214-220. 
[18] F. Fourcade, M. Delawarde, L. Guihard, S. Nicolas, A. Amrane, Electrochemical Reduction Prior to Electro-Fenton Oxidation of Azo Dyes: Impact of the Pretreatment on Biodegradability, Water Air Soil Poll. 224 (2012) 1385-1396.

[19] S. Yahiat, F. Fourcade, S. Brosillon, A. Amrane, Photocatalysis as a pre-treatment prior to a biological degradation of cyproconazole, Desalination 281 (2011) 61-67.

[20] D. Mansour, F. Fourcade, N. Bellakhal, M. Dachraoui, D. Hauchard, A. Amrane, Biodegradability Improvement of Sulfamethazine Solutions by Means of an electro-Fenton Process, Water Air Soil Poll. 223 (2012) 2023-2034.

[21] F. Ferrag-Siagh, F. Fourcade, I. Soutrel, H. Ait-Amar, H. Djelal, A. Amrane,Tetracycline degradation and mineralization by the coupling of an electro-Fenton pretreatment and a biological process , J. chem. Technol. Biot. 88 (2012) 1380-1386.

[22] I. Yahiaoui, F. Aissani-Benissad, F. Fourcade, A. Amrane, Removal of tetracycline hydrochloride from water based on direct anodic oxidation $\left(\mathrm{Pb} / \mathrm{PbO}_{2}\right.$ electrode) coupled to activated sludge culture, Chem. Eng. J. 221 (2013) 418-425.

[23] N. A. Salles, F. Fourcade, F. Geneste, D. Floner, A. Amrane, Relevance of an electrochemical process prior to a biological treatment for the removal of an organophosphorous pesticide, phosmet, J. Hazard. Mater. 181 (2010) 617-623.

[24] M. Assassi, F. Fourcade, F. Geneste, D. Floner, R. Maachi, A. Amrane, Combined electrochemical and biological treatment for pesticide degradation - application to phosmet, Int. J. Environ. Res. Publ. Health. 5 (2011) 41-46.

[25] J. M. Fontmorin, S. Huguet, F. Fourcade, F. Geneste, D. Floner, A. Amrane, Electrochemical oxidation of 2,4-Dichlorophenoxyacetic acid: Analysis of by-products and improvement of the biodegradability, Chem. Eng. J. 195-196 (2012) 208-217. 
[26] J. M. Fontmorin, F. Fourcade, F. Geneste, D. Floner, S. Huguet, A. Amrane, Combined process for 2,4-Dichlorophenoxyacetic acid treatment-Coupling of an electrochemical system with a biological treatment, Biochem. Eng. J. 70 (2013) 17-22.

[27] D. Belkheiri, F. Fourcade, F. Geneste, D. Floner, H. Ait-Amar, A. Amrane, Feasibility of an electrochemical pre-treatment prior to a biological treatment for tetracycline removal, Sep. Purif. Technol. 83 (2011) 151-156.

[28] I. Saidi, I. Soutrel, F. Fourcade, A. Amrane, D. Floner, N. Bellakhal, F. Geneste, Flow electrolysis on high surface electrode for biodegradability enhancement of sulfamethazine solutions, J. Electroanal. Chem. 707 (2013) 122-128.

[29] J. C. Spain, Biodegradation of Nitroaromatic Compounds, Annu. Rev. Microbiol. 49 (1995) 523-55.

[30] J. W. Raymond, T. N. Rogers, D. R. Shonnard, A. A. Kline, A review of structure-based biodegradation estimation methods, J. Hazard. Mater. 84 (2001) 189-215.

[31] D. Floner, L. Laglaine, C. Moinet, Indirect electrolysis involving an ex-cell two-phase process. Reduction of nitrobenzenes with a titanium complex as mediator, Electrochim. Acta $42(1997) 525-529$.

[32] F. Geneste, C. Moinet, Electrocatalytic activity of a polypyridyl ruthenium-oxo complex covalently attached to a graphite felt electrode, New J. chem. 28 (2006) 722-726.

[33] F. Geneste, C. Moinet, S. Ababou-Girard, F. Solal, Stability of $\left[\mathrm{Ru}^{\mathrm{II}} \text { (tpy)(bpy) }\left(\mathrm{OH}_{2}\right)\right]^{2+}-$ Modified Graphite Electrodes during Indirect Electrolyses, Inorganic chemistry 44 (2005) $4366-4371$.

[34] D. Floner, L. Laglaine, C. Moinet, Indirect electroreduction of nitrobenzenes orthosubstituted by ester, carbonate, amide or carbamate group, Electrochim. Acta 42 (1997) 20732079. 
[35] C. Moinet, Electrosynthèse organique en continu. Méthodes directes et indirectes, J. Phys. IV 4 (1994) Cl-175-Cl 184.

[36] P. N. Bartlett, E. Ghoneim, G. El-Hefnawy, I. El-Hallag, Voltammetry and determination of metronidazole at a carbon fiber microdisk electrode, Talanta 66 (2005) 869-874.

[37] K. Nejati, K. A-Zeynali, Electrochemical synthesis of nickel-iron layered double hydroxide: Application as a novel modified electrode in electrocatalytic reduction of metronidazole, Mater. Sci. Eng. C 35 (2014) 179-184.

[38] S. Lü, K. Wu, X. Dang, S. Hu, Electrochemical reduction and voltammetric determination of metronidazole at a nanomaterial thin film coated glassy carbon electrode, Talanta 63 (2004) 653-657.

[39] M. A. La-Scalea, S. H. P. Serrano, I. G. R. Gutz, Voltammetric Behaviour of Metronidazole at Mercury Electrodes, J. Braz. Chem. Soc. 10 (1999) 127-135

[40] P.C. Mandal, Reactions of the nitro radical anion of metronidazole in aqueous and mixed solvent: a cyclic voltammetric study, J. Electroanal. Chem. 570 (2004) 55-61.

[41] S. A. Özkan, Y. Özkan, Z. Sentürk, Electrochemical reduction of metronidazole at activated glassy carbon electrode and its determination in pharmaceutical dosage forms, J. Pharm. Biomed. Anal. 17 (1998) 299-305.

[42] H. Lund, O. Hammerich, Organic electrochemistry, M. Dekker, New York (2001).

[43] V. Sarria, S. Parra, N. Adler, P. Péringer, N. Benitez, C. Pulgarin, Recent developments in the coupling of photoassisted and aerobic biological processes for the treatment of biorecalcitrant compounds, Catal. Today 76 (2002) 301-315.

[44] C. Pulgarin, M. Invernizzi, S. Parra, V. Sarria, R. Polania, P. Péringer, Strategy for the coupling of photochemical and biological flow reactors useful in mineralization of biorecalcitrant industrial pollutants, Catal. Today 54 (1999) 341-352.

[45] Y. J. Israeli, L’hydrolyse du dichlorotitanocène, Bull. Soc. Chim. Fr. (1966) 837-838. 
- Treatment of metronidazole, a biorecalcitrant antibiotic, by a coupling process

- Towards a selective electroreduction of metronidazole into its amino derivative

- Enhancement of the biodegradability by indirect electrolyses with titanocene

- Efficiency of the coupling process with an overall mineralization yield of $85 \%$ 